\title{
A Test of the Twin Deficits Hypothesis for the Kenyan Economy
}

\author{
Luka K. Kiptui \\ School of Business and Economics, Kabarak University, Private Bag - 20157, Kabarak \\ E-mail: lukakiptui@gmail.com
}

\begin{abstract}
This study examines the Twin Deficit Hypothesis (TDH), which posits that a government's fiscal deficit occurs together with current account deficit through demand, interest rate and real exchange rate effects. The Keynesian theory and Mundell-Fleming framework prove the existence of the twin deficit relation, whereas the Ricardian equivalence theory negates any such relationship. Empirically also, certain studies prove the existence of the twin deficit relation, whereas several others challenge and prove that the two deficits have no relation with each other. This study therefore sought to test the Twin Deficit Hypothesis within the Kenyan context. Data was obtained from the International Financial Statistics and the World Economic Outlook of the International Monetary Fund (IMF). The data spans the period 1980-2017. An ARDL model was implemented to test the validity of the hypothesis. ARDL was preferred given the short span of data and the model's suitability for small samples. The findings indicate that budget deficits have direct positive effects on the current account. These effects are significant at $1 \%$ level of significance. The indirect effects of budget deficits on the current account are also strong. Budget deficits, interest rate and the exchange rate have significant effects on the current account. An increase in budget deficits increases interest rates and appreciates the exchange rate. This leads to deterioration of the current account. Thus the real exchange rate has highly significant effects on the current account. The conclusion is that budget deficits and the exchange rate dominate in explaining movements in the current account in the long run. The results support the Mundell-Fleming model and the twin deficit hypothesis.
\end{abstract}

Keywords: Twin Deficit Hypothesis, Mundell-Fleming Model, Budget Deficit, Current Account

DOI: $10.7176 / \mathrm{JESD} / 13-4-06$

Publication date: February $28^{\text {th }} 2022$

\section{Introduction}

The twin deficit hypothesis on the link between fiscal and external balances, recently received additional attention, given the need for adjustments by several countries of both the fiscal and external balance in the wake of the financial and economic crisis (Badinger et al., 2017). Numerous empirical studies on the determinants of the current account have confirmed the positive relation between fiscal balances and current accounts. The twin deficit hypothesis postulates that a government's fiscal deficit occurs together with a current account deficit through demand, interest rate and real exchange rate effects.

The Twin Deficit Hypothesis (TDH) is supported by the Mundell-Fleming model and the Keynesian incomeabsorption theory. As government spending outstrips tax revenues, the fiscal deficit expands. A rising fiscal deficit is thought to generate a twin deficit problem. The TDH is theoretically explained with the help of the national income accounting identity (Obstfeld et al., 1996).

$I+G+X=S+T+M$ [Injections $=$ Withdrawals], where $\mathrm{X}$ is exports, $\mathrm{M}$ imports, $\mathrm{T}$ Government revenues, $\mathrm{G}$ is Government expenditure, $\mathrm{S}$ savings and I investment; thus can be restated as follows,

$$
X-M=(T-G)+(S-I)
$$

This relation implies that the current account is directly related to saving and investment in the economy. Therefore, the policies supporting investment have a negative impact on the current account, while policy measures reducing private or public consumption have a positive impact on the current account, because they increase national savings (Fidrmuc, 2003). Also, Countries which experience large inflows of foreign capital (including foreign direct investment) necessarily face a negative current account of the same size if we ignore the changes in foreign exchange reserves. This opens the question of the sustainability of current account deficits. In general, a current account deficit is sustainable if it can be easily financed by associated foreign capital inflows. It is obviously necessary to differentiate between investment-induced and consumption-induced current account deficits, because only the former increase productivity and export capacity in the long run.

Exchange rate of currencies plays a vital role in the mechanism in which fiscal deficit is passing through and impacting the $\mathrm{CAB}$; also there are evidences of direct relation between fiscal deficit and exchange rate of currencies (M.R., 2017). Abell (1990) finds four important macro variables namely economic growth, rate of inflation, exchange rate, and money supply as directly affecting these deficits in the US. The higher interest rate, rapid economic growth, and huge investments attract foreign capital, meaning it increases imports of the country, which deteriorates current account deficit. The rate of inflation affects the relative desirability of internationally traded goods and thus the trade balance. A prior change in fiscal deficit causes changes in $\mathrm{CAB}$ not only through interest rate linkage, but also through exchange rate linkage. And finally, the influence of budget deficits on 
domestic monetary policy affects the CAB as changes in M1 (Narrow Money) are influenced by prior changes in the deficit and interest rates. These changes in M1 influence the CAB through the causality's prior relationship with interest rates. Theoretically, there are three distinct views: Keynesian theory and Mundell-Fleming framework which prove the existence of twin deficit relation, whereas the Ricardian equivalence theory negates any such relationship. Empirically also, certain studies prove the existence of twin deficit relation, whereas several others challenge and prove that the two deficits have no relation with each other.

The Mundell-Fleming model postulates that rising fiscal deficits push up interest rates. The mechanism works as follows: an expansionary fiscal policy or deficit spending reduces the government savings, and consequently the national savings (M.R., 2017).Further, as budget deficit increases, government will increase its borrowing, thereby rate of interest will increase. Decline in savings also pushes the interest rate upward in addition to the higher demand for loanable funds from the government. High interest rates cause capital inflows. The inflows appreciate the exchange rate. Exports suffer, imports rise. The trade deficit widens; hence a twin deficit problem occurs. The extent to which interest rates increase chokes investment and increases savings depend on whether the capital account is open or closed. An open capital account allows swift inflows of capital, reducing response of domestic interest rates to fiscal shocks. As a result, there will be no crowding out of private investment, but oneto-one impact on the current account. Closed capital account softens the impact of the fiscal deficit on the current account. This is attributed to sensitivity of interest rates to fiscal shocks and the likely crowding out of private investment. In the event that investment falls, savings rise, narrowing the S-I gap, hence softening the effect on the current account. Rising interest rates following a fiscal stimulus could attract attention of the monetary authorities. Intervention would entail sterilization of the foreign exchange inflows. This expands the money supply, causes prices to rise. Rising domestic prices appreciate the domestic currency, thus also worsening the current account. It is also important to check whether CAB has any impact on the fiscal deficit.

The TDH is also supported by the Keynesian absorption theory. As per this theory, the expansionary fiscal policy or higher government spending tend to enhance the income level of people. Thus, an expansionary fiscal shock under a flexible exchange rate regime will lead to an increase in current account deficit because of higher disposable income which leads to higher demand of imports, also the increase in domestic demand will increase domestic prices which will appreciate real exchange rate and reduce exports (Banday \& Aneja, 2015). As the income increases, demand for goods and services also increases and results in higher imports. Higher imports mean a deficit in the current account. That is, as budget deficits rise, output and overall economic activity increases, with a tendency to import more. This worsens the CAB.

Defining indirect effects as those materializing through channels other than income-related changes in import demand, Badinger et al. (2017) argue that the first indirect effects materialize through the interest rate channel; fiscal balances and interest rates are usually (and especially for small economies) negatively related. For example, in the case of a fiscal expansion, higher interest rates are triggered by an increase in total demand and the financing of budget deficits by bonds issuance, which induces capital inflows and leads to an appreciation of the domestic currency and thus lower net exports. Second, Obstfeld et al. (1996) using an overlapping generations model, show that fiscal deficits lead to a redistribution of income from future to present generations, thereby decreasing savings and thus negatively affecting the current account. This relationship is stronger; the more agents are liquidity constrained. Both channels are expected to amplify the direct effect of the fiscal balance on the current account, increasing the magnitude of their (positive) relationship.

At the other extreme end, the Ricardian Equivalence Hypothesis (REH) reckons that fiscal stimulus has no effect on the economy. This argument is based on tenets of the permanent income hypothesis. In models using the Ricardian equivalence hypothesis (e.g Barro, 1989), an increase in budget deficits will be offset by an increase in private savings. If Ricardian equivalence is incomplete, the effect of the fiscal balance on the current account will be reduced rather than eliminated. REH assumes that economic agents have rational expectations and forwardlooking behavior. The agents know that budget deficits now mean higher taxes in future. To smooth income in the inter-temporal setting, agents will work more and save more (or consume less) today. The rational households will save it as their consumption will be based on life cycle hypothesis because they expect to pay taxes in future, the increase in private savings is equivalent to the reduction in government savings. Therefore, that might be the reason government will not affect real interest rate and current account deficit. Savings thus rise and the S-I gap narrows, offsetting the rising fiscal deficit. Only budgetary 'surprises' or unanticipated fiscal policy could have short -term effects on the economy. REH rules out long-run effects of fiscal policy.

The Ricardians and Keynesians have differences over the effects of budget deficit caused by tax cut or tax increase (Banday \& Aneja, 2015). If the governmental expenditures remain unchanged, a reduction in taxes will not increase the consumption because the tax cut would be balanced by an increase in future tax, and tax payers would not feel better off even if their current income increases. Thus, national savings, current account balance, consumption, interest rates, and investment remain unaffected. On the other hand, proponents of Keynes believe that consumers do respond to a current tax cut by consuming more because they may expect that a higher deficit may now more likely bring higher taxes in future. This will reduce national savings, increase current account 
deficit and will affect all macro linkages between them as well. This leads to twin deficits phenomenon.

\section{Literature Review}

The literature is mixed. Some studies support the twin deficit hypothesis as others contradict. Those supporting the twin deficit hypothesis include Zubaidi et al. (2007) who use the data for Thailand over three decades in a case study. The study findings are supportive of the twin deficits hypothesis. Further econometric analysis revealed that the two financial variables (interest rate (IR) and exchange rate (EXCH)) act as inter mediating variables - that is an increased fiscal deficit causes interest rate to rise, and this in turn puts pressure on the exchange rate. The appreciation of the domestic currency causes a current account deficit. The study found that budget deficits (BD) Granger causes current account deficits $(\mathrm{CAB})$ and not the reverse. It turned out, however, that there is no evidence to support the hypothesis that $\mathrm{CA}$ causes $\mathrm{BD}$ or current account targeting. The statistical evidence suggested that the fiscal deficit if left unchecked will adversely affect the current account. Second, the connection between BD and $\mathrm{CAB}$ is detected through three channels: directly from $\mathrm{BD}$ to $\mathrm{CAB}$; indirectly from $\mathrm{BD}$ to higher IR which in turn appreciates the domestic currency and eventually leads to $\mathrm{CAB}$; and from $\mathrm{BD}$ to higher IR and leads to $\mathrm{CAB}$. Third, the dynamic analysis based on the generalized variance decomposition (GVDCs) revealed that EXCH is the most exogenous variable among the four variables in the system and IR is largely influenced by BD - that is BD Granger causes IR. From a policy perspective, a clear conclusion emerged from the empirical work. A growing BD will adversely affect the external balance and if the Thai authorities are to correct the imbalance in the current account, they cannot ignore the growing size of the BD. In addition, their results suggested that increasing BD will crowd private investments through its effect on IR.

Piersanti (2002) investigated the macroeconomic effects of the current and expected future budget deficits. It is shown that current and expected future budgeted deficits are positively correlated with the current account deficit, capital stock and real exchange rate and negatively correlated with the domestic real interest rate and consumption.

Kumhof and Laxton (2013) show that fiscal deficits can have worrisome implications if they turn out to be permanent. First, if they occur in large countries they significantly raise the world real interest rate. Second, they cause a short run current account deterioration equal to around 50 percent of the fiscal deficit deterioration. Third, the longer run current account deterioration equals almost 75 percent for a large economy such as the United States, and almost 100 percent for a small open economy.

Abbas et al. (2011) examined the relationship between fiscal policy and the current account, drawing on a large sample of advanced, emerging, and low-income economies and using a variety of statistical methods: panel regressions, an analysis of large fiscal policy and current account changes, and panel vector auto regressions (VAR). On average, across estimation methods, a strengthening in the fiscal balance by 1 percentage point of GDP is associated with a current account improvement of about 0.3 percentage point of GDP. With quarterly structural VAR using government consumption to identify fiscal policy shocks, the relationship is stronger, in the $0.3-0.5$ range. The association is stronger in emerging markets and low-income countries; in economies that are more open to trade; and when the economy is somewhat overheated to begin with. The effect is, however, notably weaker during episodes of large fiscal policy and current account changes, suggesting that fiscal policy may have a more limited role in correcting large external imbalances.

Bluedorn and Leigh (2011) investigated the effect of fiscal consolidation on the current account. They examined contemporaneous policy documents, including Budget Speeches, Budgets, and IMF and OECD reports, to identify changes in fiscal policy motivated primarily by the desire to reduce the budget deficit, and not by a response to the short-term economic outlook or the current account. Estimation results based on this measure of fiscal policy changes suggested that a 1 percent of GDP fiscal consolidation raised the current account balanceto-GDP ratio by about 0.6 percentage point, supporting the twin deficits hypothesis.

Aqeel et al. (2000) investigated the short and long-run relationship between budget deficit and trade deficit using co-integration analysis and error-correction methodology. Also Granger trivariate causality tests were performed. This is done to avoid the methodological problem of the third missing variable, $\mathrm{X}$, in the bi variate causality tests. X could be a third variable such as GDP, exchange rate, interest rate, price and money supply. The study uses annual data to carry out ECM and Granger trivariate causality tests. The empirical results indicated that the budget deficit had positive significant long-run effect on the trade deficit in Pakistan. However, during the short run the causal effect is negative between budget deficit and current account balances. Furthermore except for interest rate, other policy variables like economic growth, exchange rate and money supply do affect current account deficit directly and could be used more effectively in Pakistan to reduce the twin deficit.

M.R. (2017) used long-term annual data for the period 1980-1981 to 2012-2013 on Indian economy and vector error correction method to prove that there exists long-term positive association between fiscal deficit and current account deficit, and hence can be regarded as 'twin deficits'. Using structural VAR method, it proved that fiscal deficit is in line with the pattern illustrated in Keynesian absorption theory and Mundell-Fleming model in regard to its impact on current account deficit. The article negates the relevance of Ricardian equivalence theory in the Indian context. 
Badinger et al. (2017) used a panel of 73 countries over the period 1985-2012 to test for both direct effects of fiscal rules on the current account and also consider, whether more stringent fiscal rules affect the relationship between the fiscal balance and the current account. The study arrives at three main results: (i) It confirms the results of previous studies through finding a positive relationship between the fiscal balance and the current account; (ii) there is no significant direct effect of fiscal rules on the current account; and (iii) the magnitude of the effect of the fiscal balance on the current account is significantly reduced, when stringent balanced budget or debt rules are in place.

Banday and Aneja (2015) examined the short- and long-run relationship between budget deficit and current account deficit in India using yearly data for the period 1990-2013, by using different time series techniques: the unit root test, Johansen co-integration, the vector error-correction methodology, and the Granger causality. They find bi-directional causality and confirm the long-run association among the variables. The results indicate that the twin deficits hypothesis does exist in India.

Bhat \& Sharma (2018) scrutinize the asymmetric interactions between current account deficit and gross fiscal deficit in case of a growing and dynamically integrated economy, namely, India. The study confirmed the longrun co-movements of current account deficit and gross fiscal deficit and therefore refuted the Ricardian Equivalence proposition and validated the twin-deficit hypothesis. The two variables are found to share asymmetric linkages - both in the short run and in the long run. The asymmetry indicates that positive changes are more influential than their negative counterparts in the short run, whereas in the long run, only the positive changes are found to alter the external balance statistically. The asymmetric impact of fiscal deficits on the current account balance of a country may arise due to its asymmetric impact on aggregate demand through consumption inflexibility (ratchet effect) and the existence of liquidity constraints. The other control variables used in the study are also found to have co integration with the current account deficit, but the relationship is symmetrical in the long run, even though it is asymmetrical in the short run. The study finally uses the asymmetric cumulative dynamic multipliers to examine the route of asymmetries and adjustments over the course of time. The dynamic multipliers also confirmed the study findings.

Fidrmuc (2003) provide evidence for twin deficits in several countries, although differences emerge between the 1980s and the 1990s. On the other hand, Islam (1998) examines empirically the causal relationship between budget deficits and trade deficits for Brazil from 1973:1Q through 1991:4Q. This relationship is investigated in the context of Granger's causality test. Empirical results suggested the presence of bilateral causality between trade deficits and budget deficits. In addition, Kearney and Monadjemi (1990) utilized the vector auto regressive (VAR) technique to examine the international evidence from eight countries on quarterly data over the period of floating exchange rates from 1972: I-1987: IV. The evidence is consistent with a temporary twin deficits relationship.

Lack of support for the twin deficit hypothesis is found in Basu and Datta (2005) who undertook an econometric exercise to study the impact of the fiscal deficit on India's external accounts since the mid-1980s and found an absence of co integration between the budget and current account deficits. Further, an absence of co integration between the savings rate and the fiscal deficit-GDP ratio also negated the Ricardian Equivalence Hypothesis. They found that a high fiscal deficit was sustained by a simultaneous and independent increase in the savings ratio. The paper does not find any support for the existence of the twin deficit hypothesis in the Indian economy. And since Indian economic agents were found not to follow Ricardian Equivalence behavior, they concluded that unlimited growth of fiscal deficit runs the risk of external instability.

Grier and Ye (2009) do a simple test for the existence of a long-run equilibrium relationship between budget and current account deficits by comparing the number and timing of their structural shifts. They find that the two series are not closely related either in their number of breaks or in their timing of structural shifts. There is a budget balance mean shift with no corresponding trade balance shift, and two subsequent trade balance mean shifts occur while the budget balance displays a constant secular mean. They thus conclude that over the long run, the deficits are not twins. Each series has structural breaks that are largely independent of each other so they are not twins at all over the long run. However, once they allow for these secular shifts, the short-run dynamics reveal a very strong resemblance.

\section{Methodology}

\subsection{Data}

Data is obtained from the International Financial Statistics and the World Economic Outlook of the International Monetary Fund (IMF). The data spans the period 1980-2017. The current account (CAB) and budget deficits (BD) have had positive correlation as depicted in Figure 1. The real exchange rate (RER=nominal exchange rate * US $\mathrm{CPI} /$ Kenya CPI) is also positively correlated with the current account (Figure 2). A depreciation of the shilling is positively correlated with an improvement of the current account and vice-versa. 
Figure 1: Trends in BD and CAB

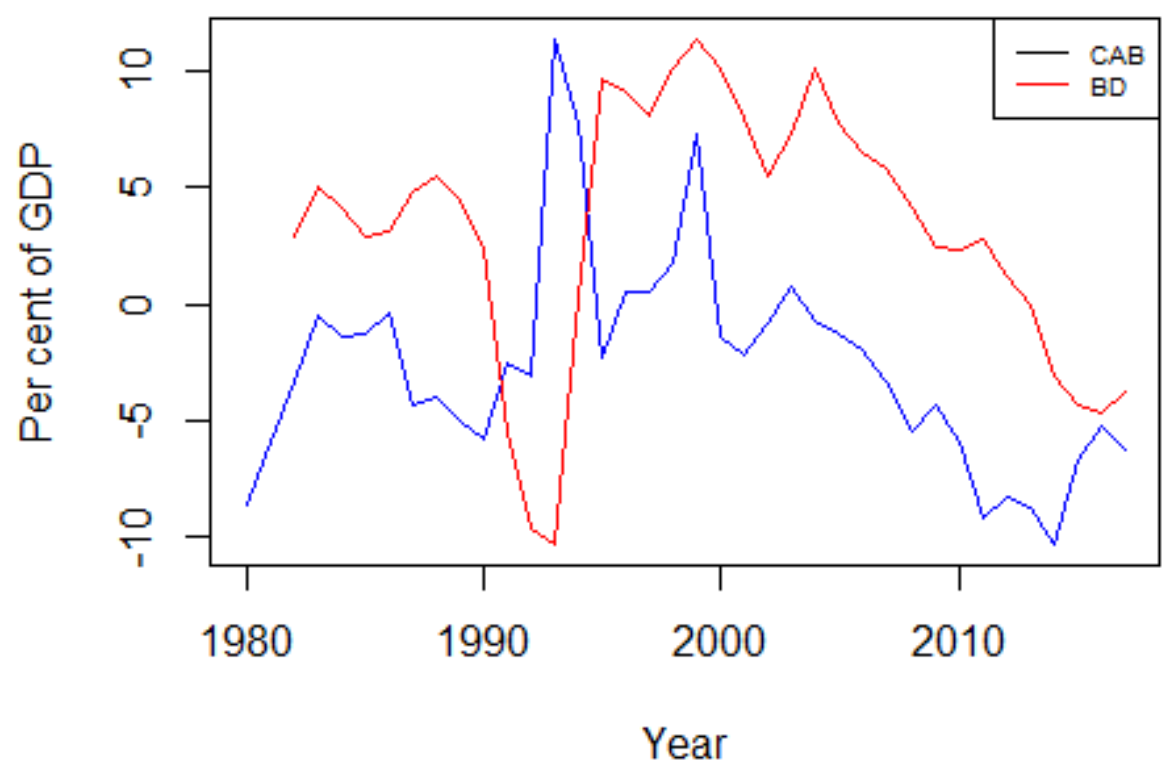

Figure 2: Tends in $\log (\mathrm{RER})$ and CAB

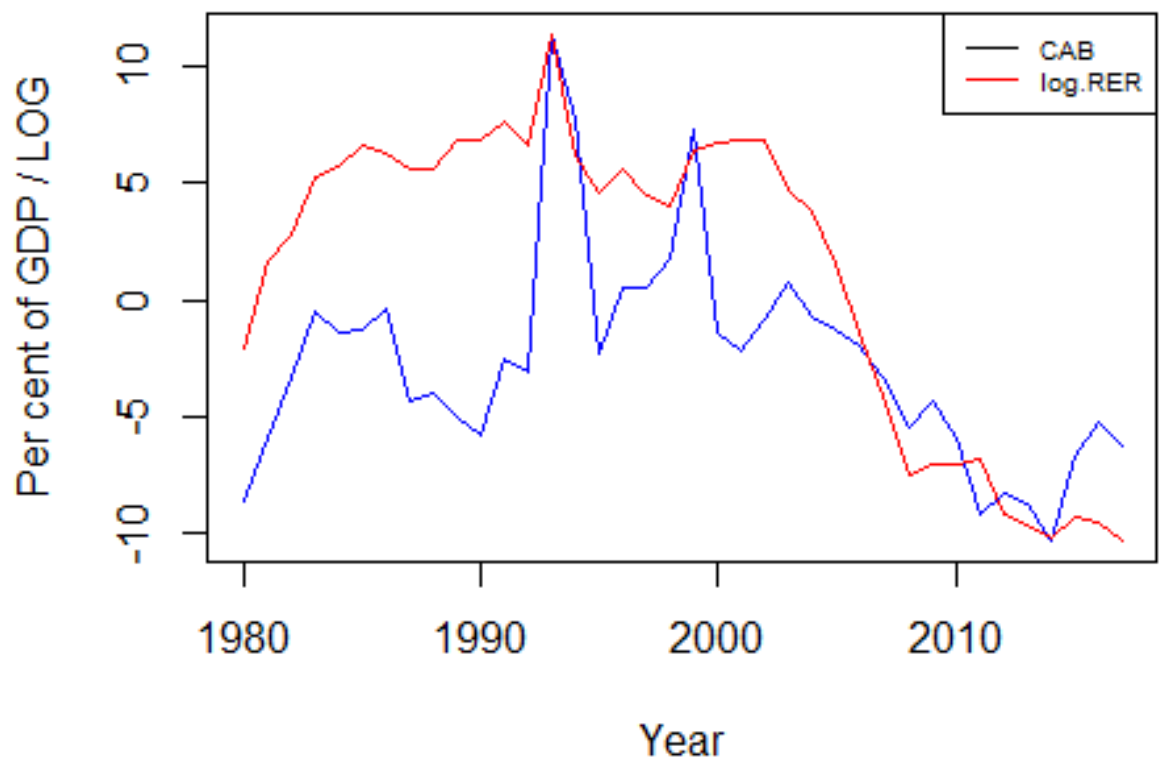

\subsection{Econometric Methods}

An ARDL model is implemented to test the validity of the twin deficit hypothesis in Kenya. Empirical tests target to confirm the Mundell-Fleming model and the Keynesian absorption-income theory. ARDL is preferred given the short span of data and the model's suitability for small samples. ARDL relies on estimation of single equation hence fewer parameters need to be estimated. It doesn't matter also if the variables are integrated of order 1 or zero. The model is thus appropriate for a mix of I (0) and I(1) variables. The optimal lag length is also different across variables and can be used even if the regressors ( $\mathrm{k}$ terms) are endogenous in nature. The starting point is to check if the long run relationship exists among the variables. To test the Mundell-Fleming model, the following ARDL models are specified:

$$
\begin{gathered}
\Delta C A B=\beta_{0}+\sum_{i=1}^{m} \beta_{1 i} \Delta B D_{t-i}+\sum_{i=1}^{n} \beta_{2 i} \Delta G R_{t-i}+\sum_{i=1}^{p} \beta_{3 i} \Delta I N T R_{t-i}+\beta_{4} C A B_{t-1}+\beta_{5} B D_{t-1}+\beta_{6} G R_{t-1} \\
+\beta_{t-1}+\varepsilon_{1 t}
\end{gathered}
$$




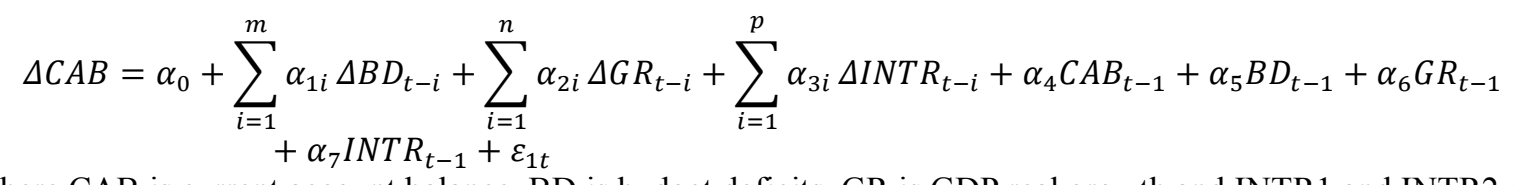

where $\mathrm{CAB}$ is current account balance, BD is budget deficits, GR is GDP real growth and INTR1 and INTR2 are interaction terms between budget deficits, interest rate (91-day Treasury bill rate [Tbill rate] or differential between Kenya T-bill and US T-bill [Kenya-US Tbill rate differential]) and the exchange rate (Shilling-US dollar exchange rate)

INTR1 = budget deficits* Tbill rate*exchange rate

INTR2=budget deficits*Kenya-US Tbill rate differential $*$ exchange rate

The test for long run relationship is based on finding if:

$\beta_{4}=\beta_{5}=\beta_{6}=\beta_{7}=0$ Against,

$\beta_{4} \neq 0, \beta_{5} \neq 0, \beta_{6} \neq 0, \beta_{7} \neq 0$

Then; $\alpha_{4}=\alpha_{5}=\alpha_{6}=\alpha_{7}=0$

Against;

$\alpha_{4} \neq 0, \alpha_{5} \neq 0, \alpha_{6} \neq 0, \alpha_{7} \neq 0$

The existence of a long run relationship is premised on lower and upper bound critical values provided in Pesaran et al. (2001) and Narayan (2005). If the calculated F-values is higher than upper bound critical values, we confirm co-integration among the variables. If calculated value falls short of the lower bound critical value, the null hypothesis of no long run relationship is accepted. Co-integration among the variables will then be rejected. If the calculated F-value falls in between the upper and lower bounds, the result is inconclusive. If long run relationship exists, the error correction representation can be formulated to derive the short -run model. We replace the one-period lagged variables by an error correction term, hence:

$\triangle C A B=\beta_{0}+\sum_{i=1}^{m} \beta_{1 i} \Delta B D_{t-i}+\sum_{i=1}^{n} \beta_{2 i} \Delta G R_{t-i}+\sum_{i=1}^{p} \beta_{3 i} \Delta I N T R 1_{t-i}+\lambda_{1} E C T 1_{t-1}+\varepsilon_{1 t}$

$\triangle C A B=\alpha_{0}+\sum_{i=1}^{m} \alpha_{1 i} \Delta B D_{t-i}+\sum_{i=1}^{n} \alpha_{2 i} \Delta G R_{t-i}+\sum_{i=1}^{p} \alpha_{3 i} \Delta I N T R 2_{t-i}+\lambda_{2} E C T 2_{t-1}+\varepsilon_{2 t}$

where $\lambda$ is the speed of adjustment and $\varepsilon$ is the residual series.

Diagnostic tests are then done on the error correction model to rule out estimation problems e.g. serial correlation, heteroskedasticity, non-normality of residual series and model instability. The following tests apply: Jarque-Bera Normality Test, Breusch-Godfrey Serial Correlation LM Test, Breusch-Pagan-Godfrey Heteroskedasticity Test, Ramsey RESET Test, Cumulative Sum of Squares (CUSUM of squares) and Cumulative Sum(CUSUM).

Once long run and short run models are identified, Granger causality between current account and fiscal deficits can be carried out using VAR framework.

\section{Empirical Results}

\subsection{Descriptive Statistics}

The mean, variance and other measures of central tendency and dispersion are compared in table 1. It is noted the variation of the $\mathrm{CAB}$ is higher compared to other macroeconomic variables.

\section{Table 1: Descriptive Statistics}

\begin{tabular}{lllll}
\hline $\mathrm{X}$ & $\mathrm{CAB}$ & $\mathrm{BD}$ & $\mathrm{GR}$ & log.RER \\
\hline min & -10.368 & -11.418 & -1.080 & 1.829 \\
max & 11.417 & 0.638 & 8.402 & 2.298 \\
range & 21.785 & 12.056 & 9.482 & 0.469 \\
median & -2.828 & -3.389 & 4.148 & 2.151 \\
mean & -2.667 & -3.885 & 3.832 & 2.078 \\
var & 21.094 & 9.385 & 5.293 & 0.021 \\
std.dev & 4.593 & 3.063 & 2.301 & 0.143 \\
coef.var & -1.722 & -0.789 & 0.600 & 0.069 \\
\hline
\end{tabular}

Direct and indirect effects of budget deficits are examined. Table 2(a) shows that budget deficits have direct positive effects on the current account as expected. These effects are significant at $1 \%$ level of significance. The indirect effects of budget deficits on the current account are also stronger, i.e. the interaction of budget deficits with interest rate and the exchange rate has significant negative effect on the current account. An increase in budget deficits is expected to increase interest rates and appreciate the exchange rate. This leads to deterioration of the current account. As expected, the real exchange rate has positive effect on the current account which is highly significant. The coefficient on the GDP growth is negative but is insignificant.

The short run model (ECM) (Table 2(b)) indicates that the interaction term is highly significant implying short term effects of the fiscal deficit as it interacts with the interest rate and the exchange rate. Additionally, it is noted (based on the speed of adjustment) that adjustment to equilibrium following any shock to the system takes 
about three quarters (Table 2(b)).

Table 2(a): ARDL Model \& Bounds Tests

\begin{tabular}{|c|c|c|c|c|c|}
\hline \multicolumn{5}{|c|}{ Dependent Variable: CAB } & \\
\hline Variable & Coefficient & Std. Error & t-Statistic & Prob. & \\
\hline $\mathrm{BD}$ & 0.772 & 0.169 & 4.563 & 0.000 & \\
\hline GR & -0.014 & 0.207 & -0.068 & 0.947 & \\
\hline LOG(RER) & 8.001 & 1.540 & 5.197 & 0.000 & \\
\hline $\mathrm{BD} * \mathrm{r} * \mathrm{EXCH}$ & 0.000 & 0.000 & -4.729 & 0.000 & \\
\hline $\mathrm{C}$ & -38.788 & 8.053 & -4.816 & 0.000 & \\
\hline F-Bounds Test & \multicolumn{4}{|c|}{ Null Hypothesis: No levels relationship } & \\
\hline Test Statistic & Value & & $\mathrm{I}(0)$ & $\mathrm{I}(1)$ & Signif. \\
\hline Actual Sample Size & 27.00 & & Finite Sample: $n=30$ & & \\
\hline F-statistic & 6.73 & & 2.53 & 3.56 & $10 \%$ \\
\hline \multirow[t]{2}{*}{$\mathrm{k}$} & 4.00 & & 3.06 & 4.22 & $5 \%$ \\
\hline & & & 4.28 & 5.84 & $1 \%$ \\
\hline
\end{tabular}

Table 2(b): ARDL Short-run Model

\begin{tabular}{|l|c|c|c|c|}
\hline Dependent Variable: D(CAB) & \multicolumn{3}{l|}{} \\
\hline Variable & Coefficient & Std. Error & t-Statistic & Prob. \\
\hline D(CAB(-1)) & 0.288 & 0.101 & 2.861 & 0.010 \\
\hline D(DEF_R_EXCH) & 0.000 & 0.000 & -8.302 & 0.000 \\
\hline ECT(-1)* & -1.254 & 0.176 & -7.140 & 0.000 \\
\hline R-squared & 0.817 & & Mean dependent var & -0.020 \\
\hline Adjusted R-squared & 0.801 & & S.D. dependent var & 4.414 \\
\hline S.E. of regression & 1.967 & & Akaike info criterion & 4.295 \\
\hline Sum squared resid & 92.827 & & Schwarz criterion & 4.439 \\
\hline Log likelihood & -54.982 & & Hannan-Quinn criter. & 4.338 \\
\hline Durbin-Watson stat & 1.644 & & & \\
\hline
\end{tabular}

The estimation is repeated by replacing interest rate variable with interest rate differential (namely, KenyaUS 91-day Treasury bill differential). The results obtained remained fairly consistent leading to similar conclusions (see Tables 3(a) and 3(b)).

Table 3(a): ARDL Model \& Bounds Test

\begin{tabular}{|c|c|c|c|c|c|}
\hline \multicolumn{6}{|c|}{ Dependent Variable: CAB } \\
\hline Variable & Coefficient & Std. Error & t-Statistic & Prob. & \\
\hline $\mathrm{BD}$ & 0.688 & 0.163 & 4.227 & 0.001 & \\
\hline GR & -0.009 & 0.211 & -0.040 & 0.968 & \\
\hline LOG(RER) & 8.141 & 1.566 & 5.200 & 0.000 & \\
\hline BD*RDIFF*EXCH & -0.001 & 0.000 & -4.610 & 0.000 & \\
\hline $\mathrm{C}$ & -39.436 & 8.197 & -4.811 & 0.000 & \\
\hline \multicolumn{2}{|l|}{ F-Bounds Test } & \multicolumn{3}{|c|}{ Null Hypothesis: No levels relationship } & \\
\hline Test Statistic & Value & & $\mathrm{I}(0)$ & $\mathrm{I}(1)$ & Signif. \\
\hline F-statistic & 6.85 & & \multicolumn{2}{|c|}{ Finite Sample: $n=30$} & \\
\hline $\mathrm{k}$ & 4.00 & & 2.53 & 3.56 & $10 \%$ \\
\hline \multirow[t]{2}{*}{ Actual Sample Size } & 27.00 & & 3.06 & 4.22 & $5 \%$ \\
\hline & & & 4.28 & 5.84 & $1 \%$ \\
\hline
\end{tabular}


Table 3(b): ARDL Short-run Model

\begin{tabular}{|l|c|c|c|c|}
\hline Dependent Variable: D(CAB) & \multicolumn{5}{|c|}{ t-Statistic } & Prob. \\
\hline Variable & Coefficient & Std. Error & 2.763 & 0.012 \\
\hline D(CAB(-1)) & 0.280 & 0.101 & -8.117 & 0.000 \\
\hline D(BD*RDIFFEXCH) & -0.001 & 0.000 & -7.206 & 0.000 \\
\hline ECT(-1) & -1.231 & 0.171 & Mean dependent var & -0.020 \\
\hline R-squared & 0.816 & & S.D. dependent var & 4.414 \\
\hline Adjusted R-squared & 0.800 & & Akaike info criterion & 4.302 \\
\hline S.E. of regression & 1.973 & & Schwarz criterion & 4.446 \\
\hline Sum squared resid & 93.434 & & Hannan-Quinn criter. & 4.344 \\
\hline Log likelihood & -55.071 & & & \\
\hline Durbin-Watson stat & 1.625 & & & \\
\hline
\end{tabular}

The Granger causality tests are given in table 4 . There is bidirectional (feedback) causality between the current account and budget deficits. Moreover, growth is significant Granger cause of CAB at $10 \%$ level of significance. Table 4: Granger Causality Tests

\begin{tabular}{ll}
\hline $\mathrm{H} 0$ & WaldTests (Chi.Square) \\
\hline Change in BD causes changes in CAB & $7.277(0.026)^{* *}$ \\
Change in CAB causes changes in BD & $13.285(0.001)^{* * *}$ \\
Change in LOG(RER) causes changes in CAB & $0.970(0.616)$ \\
Change in GR causes Changes in CAB & $5.372(0.068)^{*}$ \\
\hline
\end{tabular}

\section{Conclusion}

The conclusion is that budget deficits and the exchange rate dominate in explaining movements in the current account in the long run. The results support the Mundell-Fleming model and the twin deficit hypothesis.

\section{References}

Abbas, S. A., Bouhga-Hagbe, J., Fatás, A., Mauro, P., \& Velloso, R. C. (2011). Fiscal policy and the current account. IMF Economic Review, 59(4), 603-629.

Abell, J. D. (1990). Twin deficits during the 1980s: An empirical investigation. Journal of Macroeconomics, 12(1), $81-96$.

Aqeel, A., Nishat, M., \& Qayyum, A. (2000). The twin deficits phenomenon: Evidence from pakistan [with comments]. The Pakistan Development Review, 535-550.

Badinger, H., Fichet de Clairfontaine, A., \& Reuter, W. H. (2017). Fiscal rules and twin deficits: The link between fiscal and external balances. The World Economy, 40(1), 21-35.

Banday, U. J., \& Aneja, R. (2015). The link between budget deficit and current account deficit in indian economy. Jindal Journal of Business Research, 4(1-2), 1-10.

Barro, R. J. (1989). The Ricardian approach to budget deficits. Journal of Economic Perspectives, 3(2), 37-54.

Basu, S., \& Datta, D. (2005). Does fiscal deficit influence trade deficit? An econometric enquiry. Economic and Political Weekly, 3311-3318.

Bhat, J. A., \& Sharma, N. K. (2018). The twin-deficit hypothesis: Revisiting Indian economy in a nonlinear framework. Journal of Financial Economic Policy, 10(3), 386-405.

Bluedorn, J., \& Leigh, D. (2011). Revisiting the twin deficits hypothesis: The effect of fiscal consolidation on the current account. IMF Economic Review, 59(4), 582-602.

Feldstein, M., \& Horioka, C. (1980). Domestic saving and international capital flows the economic journal vol. 90.

Fidrmuc, J. (2003). The Feldstein-Horioka puzzle and twin deficits in selected countries. Economics of Planning, $36(2), 135-152$.

Grier, K., \& Ye, H. (2009). Twin sons of different mothers: The long and the short of the twin deficits debate. Economic Inquiry, 47(4), 625-638.

Islam, M. F. (1998). Brazil's twin deficits: An empirical examination. Atlantic Economic Journal, 26(2), 121-128.

Kearney, C., \& Monadjemi, M. (1990). Fiscal policy and current account performance: International evidence on the twin deficits. Journal of Macroeconomics, 12(2), 197-219.

Kumhof, M., \& Laxton, D. (2013). Fiscal deficits and current account deficits. Journal of Economic Dynamics and Control, 37(10), 2062-2082.

M.R., A. R. (2017). "Twin deficits" hypothesis: An assessment of relationship and transmission mechanism in India. Foreign Trade Review, 52(1), 15-29. https://doi.org/10.1177/0015732516650825

Narayan, P. K. (2005). The saving and investment nexus for china: Evidence from cointegration tests. Applied Economics, 37(17), 1979-1990. 
Obstfeld, M., Rogoff, K. S., \& Wren-Lewis, S. (1996). Foundations of international macroeconomics (Vol. 30). MIT press Cambridge, MA.

Pesaran, M. H., Shin, Y., \& Smith, R. J. (2001). Bounds testing approaches to the analysis of level relationships. Journal of Applied Econometrics, 16(3), 289-326.

Piersanti, G. (2002). Expected future budget deficits, the real exchange rate and current account dynamics in a finite horizon model. Journal of Economics, 77(1), 1-22.

Zubaidi Baharumshah, A., \& Lau, E. (2007). Dynamics of fiscal and current account deficits in Thailand: An empirical investigation. Journal of Economic Studies, 34(6), 454-475. 